\title{
馬尾の嵌頓を伴う脊髄クモ膜囊腫の一例
}

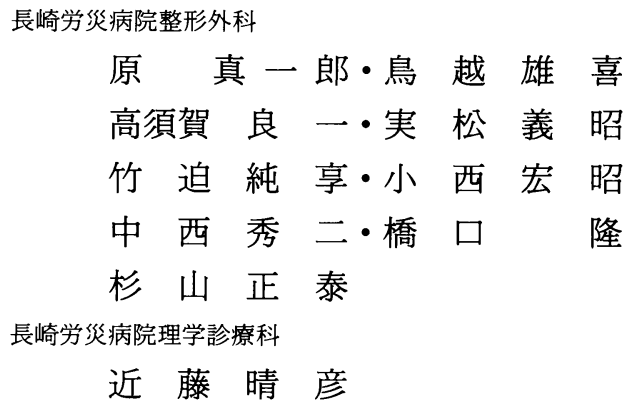

\section{Spinal Extradual Arachnoid Cyst with Incarceration of the root fila of Cauda equina}

by

Shinichirou Hara, Takayoshi Torigoe, Ryouichi Takasuga, Yoshiaki Sanematsu, Sumitaka Takesako, Hiroaki Konishi, Syuji Nakanishi, Takashi Hashiguchi and Masayasu Sugiyama

Department of Orthopedic Surgery, Nagasaki Rousai Hospital, Nagasaki, Japan

We report a case of congenital extradural arachnoid cyst. Computed tomographic myelography and magnetic resonance (MR) were complementary, and both correctly charactarized the cystic nature of the lesion. Surgical removal of the cyst and obliteration of the communication led to improvement in neurological symptoms.

\section{はじめに}

脊髄硬膜外くも膜囊腫は比較的まれな疾患である. 今回われわれは，馬尾の根系 (root fila) の囊腫内嵌 頓をみとめる脊髄硬膜外くも膜囊腫を経験したので報 告する.

症例：47 才，女性

主訴: 腰背部痛

左下肢のしびれ感，歩行困難

家族歴：特記すべきことはない

既往歴：特記すべきことはない

現病歴：昭和 47 年頃よりとくに誘因なく左大腿部の 萎縮に気づき，階段が昇りにくくなったが，さほど進 行しないので放置していた。昭和 61 年 11 月頃より腰 痛が出現し，近医にて腰部椎間板へルニアの診断で保
存的治療を行うも軽快しなかった，その頃より左大腿 部の知覚障害も認めるようになり，それらの症状が徐々 に進行したため昭和 63 年 9 月当科紹介となった。

初診時所見 : 左 $\mathrm{L}_{2,3}$ 領域の知覚鈍麻を認めた. 左の 膝蓋腱反射の低下, 両アキレス腱反射の方進, 左腸腰 筋，大腿四頭筋，前頸骨筋の筋力低下，左大腿周径の 減少を認めた。膀胱直腸障害は認められなかった（図 1 ).

$\mathrm{X}$ 線学的所見：単純 $\mathrm{X}$ 線写真では椎弓根間の拡大, 椎弓根の破壊像は明確ではないが，椎体後面の侵触像 （scalloping）を認めた（図 2).

MRI 所見：第 11 胸椎上縁より第 2 腰椎下縁かけて 脊柱管の拡大を認め, 同部の脊柱管後面に上下に長く 占拠性病変が存在した。この病変の頭側と尾側には硬 膜外脂肪が存在した．春髄および周囲のくも膜下腔は 


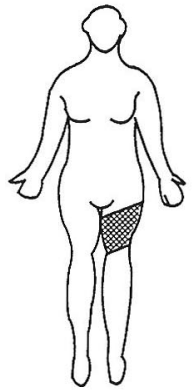

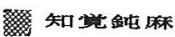

反射

PTR

ATR

Babinski clonus

MMT

Ilio.

Quad.

T. A.

F. H. L.

大腿周径 $(\mathrm{cm})$

下腿周径 $(\mathrm{cm})$
右左

$+$

H

$\pm \quad+$

53

53

54

$5 \quad 5$

\begin{tabular}{ll}
$47 \quad 42$ \\
\hline 3
\end{tabular}

$33 \quad 32$

前方に偏在していた。この病変部位の信号強度は $\mathrm{T}_{1}$ 強 調画像 (SE400/35) で脳脊髄液と同様の低信号を示し, プロトン密度画像 (SE2000/35), $\mathrm{T}_{2}$ 強調画像 (SE2000/ 92) で高信号を示した（図 3 ).

脊髄造影所見：MRI で認められた占拠性病変内に造 影剤が貯留し，それに一致して不完全ブロックを認め た (図 4).

CTM 所見：硬膜外の造影剂貯留とそれによる硬膜 囊の軽度圧排を認めた。一部椎間孔まで，造影剤の流 出をみた（図 5 ).

図 1 入院時現症

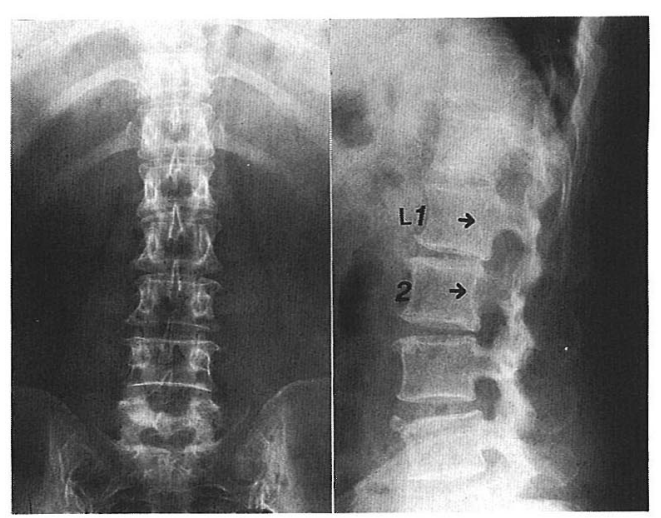

図 2 単純 X線写真

側面像で $\mathrm{L}_{1,2}$ の椎体後面に侵蝕像を認める.

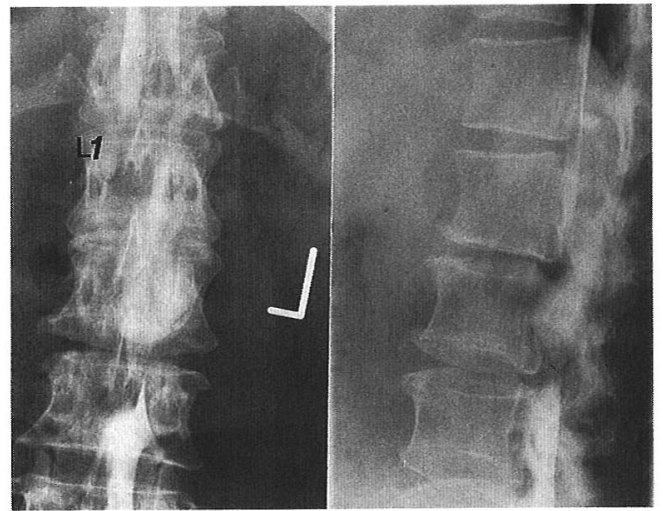

图 4 myelography MRI で認められた占拠性病変内に造影剤の貯留 像を認める。

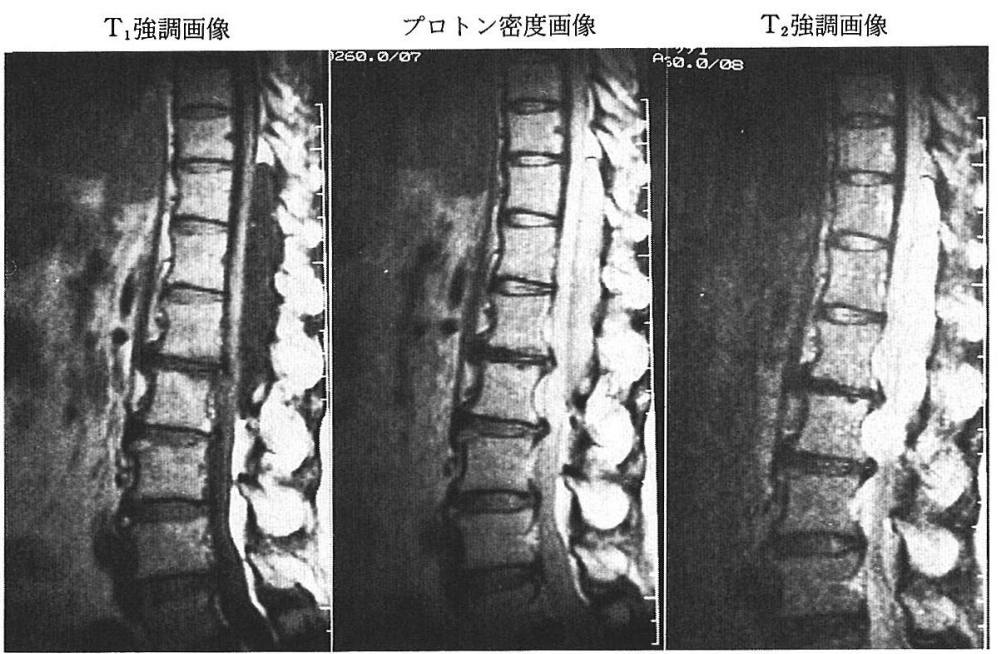

园 3 MRI

第 11 胸椎上縁より第 2 腰椎下線にかけて占拠性病変が存在し, $T_{1}$ 強調画像で低信号, プロトン密度画像 $\mathrm{T}_{2}$ 強 調画像で高信号を示している. 


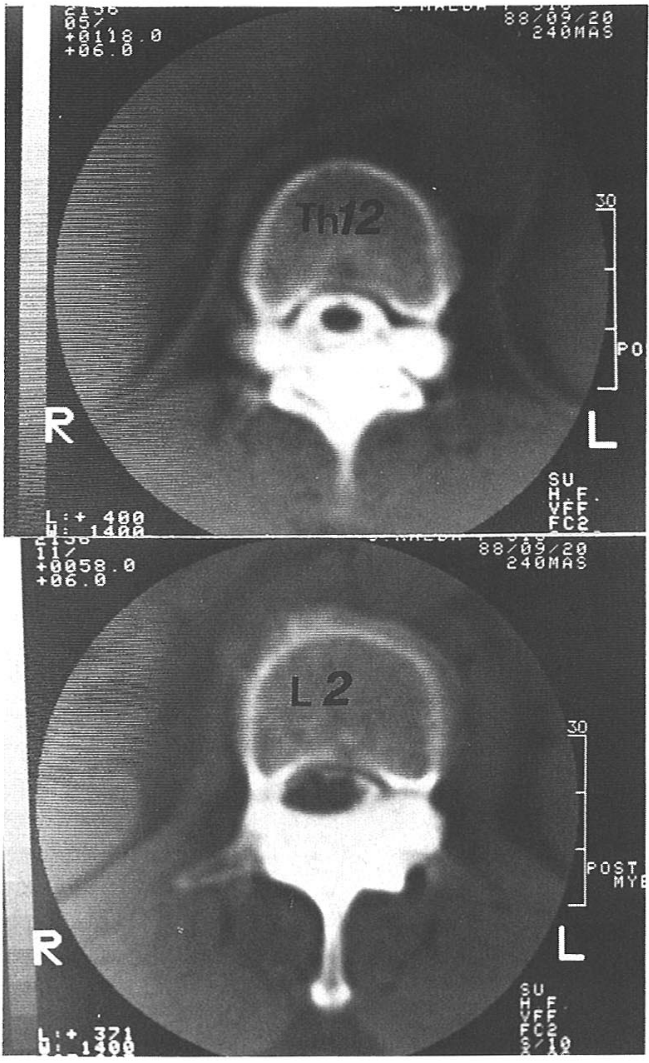

図 5 CTM

硬膜外の造影剤貯留とそれによる硬膜囊の軽度 圧排を認める。

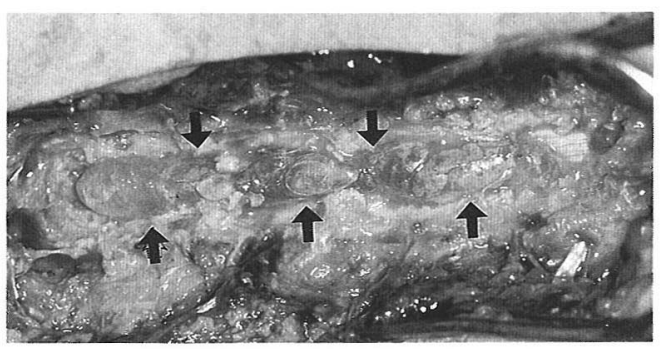

図 6 症例の術中写真, 多房性の囊腫が, 硬膜後方に 存在している。

以上の所見より，占拠性病変は硬膜外に存在しクモ 膜下腔と交通を有する囊包状のものであると推定し， 脊髄硬膜外くも膜囊腫を疑った。手術は, 第 11 胸椎加 ら第 2 腰椎まで椎弓切除術を行った。椎弓切除に際し ては術後の構築性を考慮して椎間関節は可及的に温存

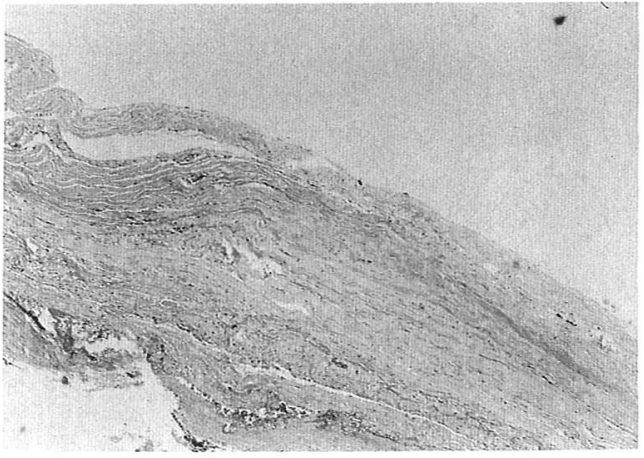

図 7 切除標本の光顕像

囊腫の壁は肥厚した膠原織維よりなる。

(H.E.染色 $\times 40)$

した。術中所見では，第 11 胸椎から第 2 腰椎におよぶ 多房性の囊腫が，硬膜後方に存在していた(図 6 )。こ の囊腫は第 12 胸椎の高位で茎を通して硬膜左後方と連 絡しており，3本の根糸が囊腫内に嵌頓していた。囊 腫を摘出した後，根系は硬膜内に還納した。硬膜欠損 部は筋膜で覆った。

組織学的所見：囊腫の壁は肥厚した膠原繊維よりな り，一部には石灰化がみられた。壁の内面には内皮細 胞は存在せず，炎症像もみられなかった。クモ膜囊腫 の壁に矛盾しない所見であった（図7）。

術後経過：術後 1 年 4 力月を経た現在, 知覚障害は 認めず，筋力は術前 3 であったものが 4 に回復しつつ ある。

\section{考察}

蓨髄クモ膜囊腫は，比較的まれな疾患であり，その 占拠部位により, 硬膜内, 硬膜外に分類される。前者 は脊骾腫晹の $3 \%$, 後者は $1 \%$ を占め硬膜外囊腫の発 生頻度は少ない, 自験例は, 病歴上硬膜に何ら侵襲が 加わっていないこと, 骨組織に侵触がおよび, 病理組 織像でも経過が長いことが推察され, 術中所見で硬膜 欠損が明らかであったことにより，先天性硬膜外クモ 膜囊腫と考えた。㱓髄クモ膜囊腫は文献上涉猟しえた 限りでは日本で約 50 例の報告があるが,そのうち先天 性硬膜外クモ膜囊腫は，自験例を含めて 4 例に過ぎな $\left(\right.$ ( $^{4) 677)}$. 発生機序としては先天的な硬膜の小欠損部を通 してくも膜が硬膜外に herniation を起こし, 顋室が形 成されると考えられている。

従来クモ膜囊腫は脊髄造影で診断が行われてきたが 
Cloward ${ }^{2}$ は全クモ膜囊腫中くも膜下腔と交通があるの は $58 \%$ \%゙，脊髄造影で確認されたものは $46 \%$ にすぎ ないと報告している。このように脊髄造影では診断の 困難な症例が存在するため背臥位脊髄造影や delayed CTM とどにより診断率を高める工夫が行われてきた。 最近 MRI が脊髄クモ膜囊腫の高位局在の診断に有 用であったとの報告が散見されるようになった。自験 例も $\mathrm{T}_{1}$ 強調像で囊腫が脊髄液と同程度の低信号を示 す占拠性病変として描出され, 第 11 胸椎から第 2 腰椎 まで脊柱管後方に一塊として存在し後方進入により摘 出が可能であることが判明した。

しかし自験例のごとく囊腫内に馬尾が嵌頓している 場合や, 脊髄へルニアを伴った症例の報告4)もあり脊髄 造影や CTM を MRI に併用し,くも膜下腔と囊腫との 交通の有無を知る必要がある.

また本症例は $\mathrm{T}_{2}$ 強調像で高信号を示したが,クモ膜 囊腫はこの条件で症例により低信号を示す場合もあれ ば高信号を示す場合もある ${ }^{399}$. これは褧腫中の脳脊䯣 液の流速が関係していると考えられている ${ }^{899)}$.

一方脊髄クモ膜囊腫は多彩な臨床像を呈することが 報告されている ${ }^{15)}$. 自験例も一側の大腿四頭筋萎縮を 初発症状として, 後に疼痛や知覚障害の出現をみるま で時間的な隔たりがあった．囊腫による既存の症状に 神経根が囊胞内に嵌頓したことが契機となって症状に 変化をもたらしたと推察した。

\section{ま と め}

今回われわれは, 先天性硬膜外クモ膜囊腫を経験し， その症状発現について考察を加え, 又術前の画像診断 で若干の知見を得られたので報告した。

\section{参 考 文 献}

1）青柳訓夫・早川勲・他：春髄硬膜内くも膜のう胞の臨 床像. 脳神経外科, $13: 1205-1212,1985$.

2) Cloward, R. B. : Congenital spinal extradural cysts: Case repost with review of literature. Ann. surg, 168: 1851-1864, 1968.

3) Kwang S. Kim, M. D. et al: Magnetic Resonance Imaging of a Spinal Extradural Arachnoid Cyst. Surg. Neurol, 26: 249-252, 1986.

4) Masuzawa $\mathrm{H}$, Nakayama $\mathrm{H}$ et al: Spinal cord herniation into a congenital extradural arachnoid cyst causing Brown-Sequard syndrome. Case report. J. Neurosurg, 55 : 983-986, 1981.

5）宮井一郎・北原義介・他：著明な一側大腿四頭筋萎縮 を呈した脊髄硬膜外くも膜㖶腫の 1 例. 臨床神経学, $27: 5-10,1987$.

6）中川敏幸・他：馬尾症候群を呈した脊䯣硬膜外くも膜 霟腫の一例. 日内会誌, $77: 1761,1988$.

7）中原信之介・小西均・他：胸椎部に発生した spinal arachnoid cyst $の 3$ 例. 中部整災誌, $24: 1612-1614$, 1981.

8）高橋陸正: MRI 最近の進歩, 南光堂, 東京, 1988.

9）上田久司・吉岡薰・他：脊髄クモ膜襄腫の治療経験。 中部整災誌, $32: 1191-1193,1989$. 